\title{
VETERINER HEKIMLIĞINDE MALPRAKTIS
}

\author{
Ayşe Dilruba ALAT ER ${ }^{1 \mathrm{a}}$, Gökhan ASLIM ${ }^{1 \mathrm{~b}}$ \\ ${ }^{1}$ Selçuk Üniversitesi Veteriner Fakültesi, Veteriner Hekimliği Tarihi ve Deontoloji Anabilim Dalı, Konya
}

ORCID ${ }^{\mathrm{a}}$ : 0000-0002-1597-6087, ORCID ${ }^{\mathrm{b}}$ : 0000-0001-5976-8186

*Sorumlu Yazar: Gökhan ASLIM

E-Posta: gokhan.aslim@selcuk.edu.tr
Geliş Tarihi: 11.06.2021

Kabul Tarihi: 27.08.2021

\section{ÖZET}

Günümüz veteriner hekimlerinin büyük çoğunluğu, ev hayvanlarının bakımlarıyla ilgili uygulamalara yoğunlaşmıştır. Hayvan sahipleri hayvanları ile aralarında duygusal bağ geliştirdiklerinden, tıbbi bir müdahale sonucu başarılı olunmadığında hayal kırıklığına uğrayabilmekte ve bu durum veteriner hekimin doğru prosedürleri uygulamadığı ya da prosedürleri yanlış uyguladığı düşüncesine yol açabilmektedir. Bir veteriner hekim, tıbbi bir müdahale sonucunda, bir evcil hayvanın yaralanmasına ya da ölümüne neden olduysa, bu durum malpraktis konusunu gündeme getirmektedir. Kisaca tıbbi uygulama hatası olarak tanımlanan malpraktis maddi manevi kayıplara neden olabilmektedir. Günümüzde veteriner hekimliği hizmetlerine olan talebin arttığı ve bununla paralel olarak malpraktis davalarının da arttığ görülmektedir. Bu bağlamda çalışmada, veteriner hekimliğinde malpraktis kavramının tanımlanması, yasal olarak nasıl değerlendirildiği, malpraktisi önlemek amacı ile nasıl önlemler alınması gerektiği konularına güncel bir yaklaşım sunulması amaçlanmıştır. Malpraktis konusu hem bilimsel anlamda hem de yasal anlamda veteriner hekim, hayvan sahibi ve hayvanları ilgilendiren oldukça önemli bir konudur. Uluslararası anlamda pek çok ülkede konuya ilişkin çeşitli yasal düzenlemeler ve çalışmalar mevcut olmakla birlikte Türkiye'de veteriner hekimliği mevzuatında özel bir düzenleme ve bilimsel çalışma bulunmamaktadır. Bu doğrultuda veteriner hekimliği alanında konu ile ilgili bilimsel araştırmaların artırılması ve yasal düzenlemelerin yapılması gerektiği söylenebilir.

Anahtar Kelimeler: Malpraktis; veteriner hekim; veteriner hekimliği mevzuatı; veteriner malpraktis.

\section{MALPRACTICE IN VETERINARY MEDICINE}

\begin{abstract}
The most majority of today's veterinarians focused on practices related to the care of pets. Since animal owners have developed a serious emotional bond with their animals, they may be disappointed when medical intervention is not successful, and this may lead to the thought that the veterinarian does not apply the correct procedures or performs the procedures incorrectly. If a veterinarian caused injury or death to a pet due to medical intervention, this raises malpractice issues. Malpractice, which is defined as a medical application mistake, in short, can cause material and moral losses. Today, it is seen that the demand for veterinary medicine services has increased significantly, and in parallel with this, malpractice cases have also increased. In this context, it is aimed to present an up-to-date approach to the definition of the concept of malpractice in veterinary medicine, how it is legally evaluated, and what measures should be taken to prevent malpractice. Therefore, malpractice is an important subject, either scientifically and legally, concerning veterinarians, animal owners and animals. Although various legal regulations and studies are available in many countries internationally, there are no specific regulation and scientific studies in veterinary medicine legislation in Turkey. In this context, it can suggest that should increase scientific researches and should make legal arrangements on the subject in veterinary medicine.
\end{abstract}

Keywords: Malpractice; veterinarian; veterinary legislation; veterinary malpractice. 


\section{GíRiş}

Tarihsel süreçte veteriner hekimler daha çok tarımsal üretimin parçası olan hayvanların hayatlarını kurtarmak üzerine yoğunlaşmışken (Walker, 2009), günümüz veteriner hekimlerinin büyük çoğunluğu gıda üretiminin bir parçası olmayan, ev hayvanlarının bakımlarıyla ilgili uygulamalara yoğunlaşmıştır. Başka bir ifadeyle tedavi edilen hayvanın, kendi mülk değerinin üzerinde para harcayabilen insanlara hizmet vermektedirler (Hessler, 2006).

Son yıllarda dünyada meydana gelen teknolojik ve bilimsel gelişmeler insanların yaşamını kolaylaştırmakla birlikte, yalnızlaşmalarına da yol açmaktadır. İnsanlar yalnızlıklarını evcil hayvanları sahiplenerek, onlarla dostluk bağı kurarak gidermektedirler (Erol Sarıyev, 2016). Hayvanlar geleneksel olarak hukukta mülk olarak görülseler de günümüzde hayvan severler evcil hayvanları, kişisel mülkten daha çok ailenin üyeleri, çocukları veya en yakın arkadaşları olarak görmekte, hayvanın aile içindeki rolünü "çok önemli” olarak tanımlamakta (White, 2009; Pugliese ve ark., 2019) ve onlar için birer ebeveyn gibi davranabilmektedirler (Woodward ve Bauer, 2007).

Hayvan sahipleri, pet hayvanlara bağlanmanın sonucunda hayvanları öldüğünde derin bir keder yaşamaktadırlar. Bununla birlikte pet hayvanını haksız ve/veya hatalı bir eylem nedeniyle kaybetmiş kişilerin depresyon belirtisi gösterdiği de görülmektedir (Livingston, 2004). Hayvan sahipleri hayvanları ile aralarında duygusal bağ geliştirdiklerinden, tıbbi bir müdahale sonucu başarılı olunmadığında hayal kırıklığına uğrayabilmekte ve bu durum veteriner hekimin doğru prosedürleri uygulamadığı ya da prosedürleri yanlış uyguladığı düşüncesine yol açabilmektedir
(Center ve Smeshko, 2011).

Evcil hayvanlar için sunulan veteriner hekimlik hizmetleri, nöroloji, kardiyoloji, dermatoloji gibi özel uzmanlık alanları, hastalıkların tedavileri ve koruyucu veteriner hekimlik ile ilgili geniş bir yelpazeye sahip olup (Pugliese ve ark., 2019), birçok yönden insan tıbbı ile karşılaştırılabilir (Gardiner ve ark., 2015). Veteriner hekimler birçok uzmanlık alanında dikkate değer bir biçimde gelişime uğramaktadır. Bununla birlikte hayvan sahiplerinin hayvanlarının tedavileri konusunda beklentilerinin giderek artmış, farklılaşmış ve daha karmaşık hale gelmiş olması veteriner hekimlerin sorumluluğunu net bir şekilde daha da arttırmıştır (Schnobel, 2016).

Hekimlik mesleği, yapılan iş gereği hekimler açısından oldukça riskli bir meslektir. Komplikasyonların hata olarak kabul edilmemesi ile birlikte tıbbi uygulamaların özenle yapılması da (özen borcu) gerekmektedir. Bu özen, elde var olan imkânlar ve tıbbi uygulamaların seviyesi ile orantılıdır. Hekimler uyguladıkları tedaviler sonucunda oluşacak riskten ancak kusurlu olması, yani "malpraktis" durumunda sorumlu tutulabilir (Koç, 2014).

Günümüzde veteriner hekimliği hizmetlerine olan talebin önemli oranda arttığı ve bu bağlamda malpraktis davalarının da çoğaldığı görülmektedir. Türkiye'de veteriner hekimliğinde malpraktis konusuna ilişkin yeterince bilimsel kaynağın ve yasal bir düzenlemenin bulunmaması dolayısıyla bu çalışmada, veteriner hekimliğinde malpraktis kavramının tanımlanması, yasal olarak nasıl değerlendirildiği, malpraktisi önlemek amacı ile alınması gereken önlemler konularına güncel bir yaklaşım sunulması amaçlanmıştır. 


\section{MALPRAKTIS}

\section{Malpraktis Kavramı}

Malpraktis terimi, kökenini Latince "mala" ve “praxis" kelimelerinin birleşiminden almaktadır ve "kötü, hatalı uygulama" anlamina gelmektedir. Türkçe'de ise kısaca "tıbbi uygulama hatası” ya da "tıbbi kötü uygulama” anlamina gelmektedir (Babacan ve ark., 2018). İngilizce'de “malpractice” olarak kullanılan bu kavram, Türk Dil Kurumu (TDK)'nun Büyük Türkçe Sözlüğü'nde, “özen göstermeksizin veya yanlış uygulanan tedavi sonucunda ortaya çıkan, görevi kötüye kullanma anlamına gelen hukuki durum” olarak karşımıza çıkmaktadır (TDK, 2013). Türk Tabipler Birliği’nin Meslek Etiği Kuralları İkinci Bölüm Genel Kurallar ve İlkeler başlığ 1 altında bulunan 13. maddesinde malpraktis için "bilgisizlik, deneyimsizlik ya da ilgisizlik nedeniyle bir hastanın zarar görmesi “hekimliğin kötü uygulaması" tanımı yapılmıştır (TTB, 2012).

Malpraktis, hastaların tıbbi uygulamayı yapan kişiler tarafından "kasıtsız haksız fiile" uğraması olarak da ifade edilebilmektedir (Babacan ve ark., 2018). Genel olarak malpraktis kavramı, hekimlerin, günümüz tıp teknolojisinin en gelişmiş hali ile ilgili edindiği bilgileri tıbbi uygulamalar sırasında tıbbın uygun gördüğü biçimde uygulamaması, tıp standartlarının altında hizmet vermesi ya da hiç hizmet vermemesi durumunda ortaya çıkan durumu ifade etmektedir (Değdaş, 2018). Bunun yanı sıra bu kavrama daha da geniş bir anlam yüklenerek, mevcut şartlarda hekimin yapılması uygun görülen hizmet ve bakım ile ilgili başarısız olması, tecrübeli bir hekimin göstermesi gereken performansı sergileyememesi, belirli bir standarda ulaşmış olan uygulamalarının gereğinden sapmış olması ya da standardını düşürmesi ve bundan bir zarar meydana gelmesi şeklinde de tanımlanabilmektedir (Çokar, 2009).

Malpraktis kavramını tanımlarken kullanılan “ihmal, kusur ve sorumluluk” terimlerine bakılacak olursa; "Ihmal”; "Gereken ilgiyi göstermeme, boşlama, savsaklama, savsama, önem vermeme" anlamlarına gelmektedir. "Kusur”; "Bilerek veya bilmeyerek bir işi gereği gibi yapmama” (TDK, 2020) olarak tanımlanmaktadır. Kusur, dikkatsizlik, tedbirsizlik, meslekte acemilik-yetersizlik ve özen eksikliği olarak alt kavramlarda da değerlendirilebilmektedir (Sağesen, 2013). "Sorumluluk" ise "kişinin kendi davranışlarını veya kendi yetki alanına giren herhangi bir olayın sonuçlarını üstlenmesi, sorum, mesuliyet" anlamlarını taşımaktadır (TDK, 2020).

\section{Malpraktis ile Karışabilecek Bir Kavram: Komplikasyon}

Fransizca "complication" kelimesinden dilimize geçen "komplikasyon” kelimesi TDK sözlüğüne göre (TDK, 2020) "karmaşıklık" anlamına gelmektedir. Tıpta kabul edilmiş hali ile komplikasyon terimi; "Normal risk ve sapmalar" olarak ifade edilebilmektedir (Hanc1, 2005). Komplikasyon ayrıntılı olarak; "Her türlü dikkat ve özveri ile tıbbi standartlara uyularak yapılan müdahaleye răgmen, hekimlik uygulamalarının doğası gereği, ortaya çıkma ihtimali öngörülebilen ve müdahale sonrasinda meydana gelmesi kaçınılmaz olan zararlar" olarak da ifade edilmektedir (Şahin, 2021).

Sağlık alanında hizmet veren uzmanlar, kimi uygulamalarda bazı risklerin var olduğunu bilip bu durumdan kaçınmaktadır. Günümüz hukukunda, hekimler ve sağlık alanında çalışan personeller icraatlarını "izin verilen risk" sınırları içerisinde 
yapmalıdırlar. $\mathrm{Bu}$ izin verilen riskin hekimlikteki karşılığ1 komplikasyon olup, hata olarak kabul edilmemektedir (Koç, 2014).

Malpraktis ile komplikasyonun iyi şekilde ayırt edilmesi gerekmektedir. Hekimlerin hastaya zarar verebilecek tıbbi bir müdahalede bulunması durumunda hatalı olup olmamasına göre bazı sorumlulukları olabileceği söylenmektedir. Fakat eksiksiz ve hatasız yapılmış olan teşhis ve tedavi sonucunda oluşabilecek ve hastanın da bilgisi dahilinde oluşan komplikasyonlardan hekim sorumlu tutulmamaktadır (Değdaş, 2018).

Ameliyata hazırlanma aşamaları, ameliyat esnası veya post-operatif takip aşamasında göz önünde bulundurulabilen ya da tahmin edilemeyen bazı komplikasyonlar gelişebilmektedir. Komplikasyonlardan hekimlerin sorumlu tutulmaması için gerekli bazı şartlar bulunmaktadır. Malpraktis ya da komplikasyonun oluşmasına neden olan durum ameliyat sonucunda ya da tedavi sonucunda meydana gelmektedir. Müdahale öncesinde hasta (veteriner hekimlikte hasta sahibi) mutlaka gelişebilecek komplikasyonlarla ilgili bilgilendirilmelidir ve rızası alınmış olmalıdır. Olumsuz sonucun ihmal, tedbirsizlik, dikkatsizlik gibi hatalı durumların bulunmaması şartı ile gerçekleşmiş olması gerekmektedir (Koç, 2014; Şahin, 2021). Her koşulda hekimler, bu komplikasyonları en iyi biçimde yönetmekle yükümlüdürler ve olası komplikasyonlarla ilgili önceden tedbirlerin alınmış olması gerekmektedir. Zira ilk etapta komplikasyon olarak başlayan bir durumun iyi yönetilmemesi sonucunda malpraktise dönüşmesi kaçınılmazdır. Yapılan uygulamalarda meydana gelen komplikasyonların takibinde yeterli özen gösterilmemesi, ihmal ya da hataların yapılması, hastayı zamansız taburcu etmek ya da sevk etmek malpraktise sebep olabilir (Koç, 2014).
Hekimlikte olduğu gibi veteriner hekimliğinde de komplikasyonlarla sık sık karşılaşıldığı, bu konuda dikkatli davranarak riskli uygulamalardan kaçınılması ve gerekli önlemlerin alınmasının, yapılan uygulamaların malpraktise dönüşümünün önüne geçilmesi adına yararlı olacağı söylenebilir.

\section{MALPRAKTISIIN MEYDANA GELMESI Malpraktisin Öznesi}

Hayvanlara uygulanacak tıbbi ve cerrahi her türlü müdahale ve üremenin kontrol altına alınması için yapılan kısırlaştırma işlemleri yalnızca veteriner hekimler tarafindan yapılabilmektedir (Resmi Gazete, 2004a). Bu durumda veteriner hekimler, tedavi ya da operasyon sonucunun olumsuz olduğu durumlarda, malpraktisten sorumlu olan birinci derecede meslek grubudur. Veteriner hekimlerin görev ve yetkileri de 6343 say1lı "Veteriner Hekimliği Mesleğinin İcrasına, Türk Veteriner Hekimleri Birliği ile Odalarının Teşekkül Tarzına ve Göreceği İslere Dair Kanun"un 5. maddesinde açıkça belirtilmektedir (Resmi Gazete, 1954). Veteriner hekimlerin Kanunda belirtilen görev ve yetki alanlarını bilmeleri ve mesleklerini bu doğrultuda icra etmelerinin malpraktisin önlenmesi açısından önemli olduğu söylenebilir.

Malpraktisin hukuki olarak değerlendirilmesi sırasında tıbbi uygulamayı kimin uyguladığı cezai sorumluluk açısından önem arz etmektedir. Çünkü malpraktisten bahsedilebilmesi için uygulamanın yetkili kişi tarafından yapılmış olması gerekmektedir. 6343 sayılı Kanun (Resmi Gazete, 1954) gereğince, belirtilmiş şartları yerine getiren ve veteriner hekim olma hakkını elde etmiş kişiler, yetkili kişiler olarak kabul edilmekte ve malpraktis vakalarından sorumlu tutulabilmektedir. Adı geçen Kanunda belirtilen yetkili kişi dışında biri tarafından yapılmış olan uygulamalar malpraktis kapsamına 
alınmaz. Örnek olarak bazı veteriner hekimler, sermaye sahipleri ile birlikte muvazaalı şekilde (sahibi veteriner hekim olmayan) muayenehane, poliklinik ve hayvan hastanelerinin açılmasına yardımcı olmaktadır. Bu durumda veteriner hekim olmayan kişiler hekimlik hizmeti vermekte ve hayvanlara tıbbi müdahalelerde bulunmaktadır (TVHB, 2010; TVHB, 2018). Yapilan bu müdahaleler malpraktis sayılmayacağı gibi, resmi olarak ruhsatta ismi bulunan veteriner hekimin, hiçbir müdahale yapmamasına rağmen malpraktisten sorumlu tutulması durumuyla karşı karşıya kalabileceği söylenebilir. Bununla birlikte veteriner hekim olmayan kişilerin tıbbi ve cerrahi müdahalelerde bulunması da kanunen yasak olup (Resmi Gazete, 1954; Resmi Gazete, 2004a) bu uygulamalarda bulunan kişiler için yasal yaptırımlar söz konusudur.

\section{Malpraktisin Oluşumu}

Malpraktis ilk olarak yapılmaması gerekeni yapma durumu, ikinci olarak yapılması gerekeni yapmama durumudur ve bu durumlar hastaya zarar verilmesine ya da istenmeyen bir sonucun ortaya çımasına neden olabilmektedir (Koç, 2014).

Tıbbi uygulamaların hukuka uygunluğunun belirlenmesinde bazı kriterler söz konusudur. Bunlar;

- Uygulayan kişinin yetkili olması,

- Trbbi endikasyon varllğı,

- Hastanın ve/veya hasta temsilcisinin yapılacak uygulamaya izin vermesi,

- İşlemin daha önce kabul görmüş tıbbi kurallara uygun yapılması,

- Yapılan işlemin kanun ile yasaklanmamış olması şeklinde sıralanmaktadır (Aktaş, 2021).
Malpraktisin oluşması üzerinde, vakanın niteliği, karşılaşılma sıklığı, olumsuz sonuçlanma sıklı̆ğ, bu olumsuz sonucun erken fark edilebilmesi, engellenebilmesi durumu ya da tedavi koşulları önemlidir. Bu etmenler dava açılması durumunda bilirkişi ya da yargı kararlarının verilmesini direkt olarak etkileyebilmektedir. Hekim, oluşabilecek komplikasyonlar ile ilgili eksik, hatalı işlemler yapmış, kullanılan ilacın yaygın olarak bilinen yan etkisini önemsememiş, eksik olduğunu düşündüğü bir uzmanlık alanında konsültasyona başvurmamış ya da gerekli tetkikleri yapmamış olması ve bunun sonucunda hasta zarar görmüş ise bu durumda hekim sorumluluğu altında malpraktis ortaya çıkacaktır (Koç, 2014). Ayrıca teşhis, tedavi ve bakım sırasında yapılan uygulamalarda kullanılan çeşitli tıbbi ürünler bulunmaktadır ve malpraktis olgularının bazıları doğrudan bu ürünlerin neden olduğu zarardan kaynaklanabilmektedir (Çokar, 2009).

Malpraktisi değerlendirirken hekimlerin çalışma koşulları da göz önünde bulundurulması gereken durumlar arasındadır. Herhangi bir olguda, donanımlı bir hastanede görev yapan bir hekim ile oldukça zor koşullarda tek başına çalışan bir hekimin sorumluluğu aynı olmayacağı gibi (Koç, 2014), kamuda görev yapmakta olan bir veteriner hekimle, mesleğini serbest olarak icra eden bir veteriner hekimin sorumluluğu da aynı olmayacaktır.

\section{Malpraktis Türleri ve Nedenleri}

Malpraktis iddiaları ile ilgili birbirine benzeyen ancak farklı türde iki iddia şekli bulunmaktadır. Birincisi, temel ya da geleneksel ihmal (çoğunlukla klinik hizmeti verilen yerin sorumlu olduğu hayvan/hasta sahipleri veya çevredeki kişiler için kayma, düşme veya yaralanma durumları, 
hasta/hayvan sahibinin gerekli durumlarda bir uzmana yönlendirilmemesi, normal mesai saatleri dışında hastaların 24 saat acil ve kritik bakıma erişim ya da bakım sağlayabilecek başka bir yere yönlendirilmemesi vb.), ikincisi ise veteriner hekimlerin sorumlu olduğu durumlarda yanlış uygulama ya da mesleki ihmaldir (Wilson, 2011).

Özçetin (2016) malpraktis hatalarını; Tanıda yapılan hatalar, aydınlatma ve onam hataları, tedavi sürecinde yapılan hatalar, ilaç uygulama hataları, hastane enfeksiyonları, kliniğe gelen kişilerin düşmesi, hastanın yetersiz şekilde takip edilmesinden kaynaklanan hatalar, iletişim eksikliğinden kaynaklanan hatalar, uygun olmayan ya da yanlış malzeme kullanımına bağlı oluşan hatalar şeklinde alt başlıklarda kategorize etmiştir.

Tanı/teşhis hataları: Teşhis, hastanın muayene edilmesi ve muayene sonrasında yapılacak tetkik işlemleri ile hastalığın belirlenmesi, semptomların araştırılması işlemidir(Değdaş, 2018). Yapılacak cerrahi operasyon öncesi, esnası ya da sonrasında uygulanacak tetkikler ile tanı konması sırasında yapılan hatalı girişimler sebebi ile hastanın zarar görmesi durumunda hata ortaya çıkabilmektedir. $\mathrm{Bu}$ sürecin gecikmesi, güncel olmayan, eksik ve bilimsel temele dayanmayan yöntemlerle tanının yanlış konması ya da hiç konulamaması bu kapsamda değerlendirilebilir (Koç, 2014; Çoltu, 2012). Bazı durumlarda çok hızlı teşhis koymak da, yetersiz ya da ihmalkâr gibi görünmeye sebep olabilir. Çünkü basit gibi görünen vakalarda zaman zaman gözden kaçırılabilen hususlar olabilmektedir (Wilson, 2011).

Tedavi ve tedavi sonrası uygulama hataları: Tedavi süreci hastalık teşhis edildikten sonra başlayan süreçtir (Değdaş, 2018). Yanlış doz ya da yöntemle ilaç uygulanması, tedavinin geciktirilmesi, yanlış tedavi yönteminin seçilmesi, cerrahi operasyon sırasında yapılan hatalar, gereksiz tedaviler, post-operatif bakımın yetersiz veya uygun olmayan şekilde yapılması gibi örnekler bu kapsamda değerlendirilebilir (Çoltu 2012; Koç, 2014).

Diğer hatalar: İletişim eksikliği, ekipmanların yetersizliği ya da diğer sistem yetersizlikleri (Çoltu, 2012), hekimin müdahaleden kaçınması ya da tedaviyi geciktirmesi (Değdaş, 2018) olarak örneklendirilebilir. Tıbbi bakım ve ücretlerle ilgili iletişimdeki aksaklıklar malpraktis şikâyetlerinin temel nedenlerini oluşturabilmektedir. Tibbi müdahalelerden kaynaklanan komplikasyonların ücretleri tahmin edilemeyebileceğinden, bu durum hasta sahiplerinden istenecek ücretle ilgili çeşitli sorunlara yol açabilmektedir. Veteriner hekimler tedaviyi planlama aşamasında tedavinin ne kadar süreceği ile ilgili kesin bilgi veremeyebilirler. Bu durumun doğal sonucu olarak tahmini tedavi ve ücretlerle ilgili, net bir öngörüde bulunamayabilirler. Veteriner hekimlerin, hasta sahiplerinin kabulü olmaksızın tahmini maliyetleri aşmaları da malpraktis iddialarına yol açabilmektedir. $\mathrm{Bu}$ durum aynı zamanda maliyetlerin karşılanmasını da zorlaştırmaktadır (Wilson, 2011).

\section{VETERINER HEKIMIN SORUMLULUĞU}

\section{Hayvanların Hukukî Konumu}

Hayvanların tedavi edilmesi, veteriner hekimlerin en önemli sorumluluklarından biridir. $\mathrm{Bu}$ nedenle tartışmalı olsa da hukuken eşya sayılan ancak yaşama hakkına sahip oldukları da kanun tarafından ifade edilen hayvanlar, veteriner hekimlerin birincil sorumluluk alanına girerler (Resmi Gazete, 2004a; Oral, 2014).

Almanya (Alman Medeni Kanunu, 2002; Federal Alman Cumhuriyeti Anayasas1, 2014), 
İsviçre (İsviçre Medeni Kanunu, 1907), Avusturya (Avusturya Medeni Kanunu, 1988), Çekya (Çekya Medeni Kanunu, 2012) gibi hayvanlara saygının da yasal bir değer olarak kabul edildiği ve hayvanların belirli yasal korumadan yararlanmasina izin veren ülkeler vardır. Türkiye'de ise 2004 yılında çıkartılan 5199 sayıl1 "Hayvanları Koruma Kanunu" nda hayvanlar ile ilgili pek çok tanım yer almakla birlikte, hayvanların eşya olmadığı ile ilgili herhangi bir hüküm bulunmamaktadır (Resmi Gazete, 2004a). Bahsedilen uluslararası hukuk sistemlerindeki görüşlerin Türk Hukuk sistemi tarafindan benimsenebileceği düşünülse de, hayvanları ayni hak konusu olmalarından dolayı Türk Hukuk sisteminde halen eşya olarak kabul edilmektedir (Oral, 2014).

Eşya, hukuki anlamda "üzerinde bireysel hâkimiyet sağlanabilen, ekonomik bir değer taşıyan, kişi ve hayvanlar dışındaki cismanî varlık" olarak tanımlanmaktadır. Erol Sarıyev (2016), hayvanların eşya benzeri olduklarını kabul eden bazı yazarların mevcut olduğundan bahsetmiştir. $\mathrm{Bu}$ yazarlar (Oğuzman ve ark., 2012), hayvanların yine de taşınır veya taşınmaz üzerinde doğrudan doğruya egemenlik yetkisi veren ve herkese karşı ileri sürülebilen haklar (ayni hak) (TDK, 2020) konusu olabileceğini savunmaktadırlar. Hayvanların alımsatım işlerine konu olabileceği, üzerlerinde mülkiyet hakkı ve rehin gibi aynî hakların varllğ̆ (Resmi Gazete, 2004a) göz önünde bulundurulduğunda da Türk Hukukunda eşya olma özelliğinin devam ettiği söylenmektedir. Hayvanların hukuken eşya sayıldığını kabul edenler, ekonomik değerinin varlığının önemsiz olsa da, üzerinde fiilen hâkimiyet kurulabilen, kişisel niteliği olmayan, sınırları belirgin maddi varlıkların hukuken eşya sayıldığını düşünmektedirler. Türkiye'de hayvanların hukuken eşya sayılmadığını söyleyebilmek için bahsedilen ülkeler gibi kanuni düzenlemelere gereksinim duyulmaktadır (Erol Sarıyev, 2016).

Türkiye'de yürürlükte olan kanunlarda aynî hak tarafindan sağlanan tasarruf ve korunma hakkından, hayvanlar üzerinde hak sahibi olan bireyler faydalanmaktadır. Bunun sonucu olarak, veteriner hekim tarafından, hukuken eşya olarak kabul edilen hayvanlara uygulanacak tedavi sonras 1 oluşabilecek hukukî (adli yargı-tazmin davası), cezaî (adli yarg1-ceza davası), idarî (kurum içi soruşturma) ya da meslekî (veteriner hekimleri odası, haysiyet divanı vd.) (Sağesen, 2013) sorumluluktan söz edilebilmesi için, söz konusu hayvanların ev ve süs hayvanı, kontrollü hayvan veya sahipli çiftlik hayvanı şeklindeki sahipli hayvanlar statüsünde olmas1 gerekmektedir (Erol Sarıyev, 2016; Resmi Gazete, 2004a). Çünkü herhangi bir olumsuzluk neticesinde "hayvanda oluşabilecek zarardan hayvan sahibinin de zarara uğraması durumunda" veteriner hekimin sorumluluğundan söz edilebilmektedir (Erol Sarıev, 2016).

\section{Veteriner Hekimin Sorumluluğu}

Gerek beşeri, gerekse de veteriner hekimliğin "izin verilen risk (komplikasyon)" kavramı çerçevesinde yerine getirilmesi gerekmektedir. Kabul edilen normal risk ve sapmalardan kaynaklanabilecek sorunlar hekimi sorumlu k1lmamaktadır. Fakat hekimlik mesleğinin "özenle yürütülmesi zorunluluğu (özen borcu)" vardır. Hekimlerin uyguladıkları tedavilerin sonrasinda meydana gelebilecek riskten sorumlu tutulabilmesi için ancak bir kusur işlemesi gerekmektedir (Tuğcu ve ark., 2009).

Veteriner hekimlerin uymakla yükümlü oldukları mesleki etik kurallar mevcuttur ve bu kurallar içerisinde sorumlu oldukları etik ilkeler bulunmaktadır. $\mathrm{Bu}$ ilkeler, temel olarak zarar 
vermeme, yararlılık, özerklik ve adalet ilkesidir. Bu temel etik ilkelere yardımc etik ilkeler ise aydınlatılmış onam, gizliliğe saygı, sır saklama, sadakat, sözünde durma, kötü davranmama ve eşitlik ilkeleridir (Yaşar, 2014). Fakat hem ceza kanununda hem medeni kanunda hekimlerin "cezaî ve hukukî", sorumluluklarını düzenleyen özel bir madde bulunmamaktadır. Hekimlerin uygulamalarındaki sorumlulukları çeşitli yasa, tüzük ve yönetmeliklerle belirlenmiştir. Meslek etiği kuralları ile ilgili yasalarda bulunan genel tanımlara dayanılarak, cezaî ve hukukî yönden hekimler sorumlu hale gelmektedirler (Tuğcu ve ark., 2009; Çelik, 2020).

“Türk Veteriner Hekimleri Birliği Hizmetlerinin Yürütülmesine İlişkin Uygulama Yönetmeliği”nin Sekizinci Bölüm "Deontoloji” başlığı altında veteriner hekimlerin görev ve sorumlulukları esnasında malpraktis ile ilişkili olabilecek çeşitli maddeler bulunmaktadır. $\mathrm{Bu}$, maddelerde veteriner hekimlerin, genel hekimlik kurallarına aykırı aldatıcı teşhis ve tedavi yapamayacağı (78. madde); Veteriner hekimlerin, uygulayacağı tedavide maddi ve manevi en emin yolu seçmesi gerektiği ve önceden denenmiş ve yarar sağlamayacağı anlaşılmış yöntemleri uygulamaktan sakınması gerektiği (79. madde); Veteriner hekimlerin, bilimsel yöntemlere uyarak teşhis koyması ve gereken tedaviyi yapması, hastalığın iyileşme ile sonuçlanmamasının veteriner hekimin başarısızlığını göstermediği gibi bu nedenle kınanmasının da kabul edilemeyeceği (86. madde) hükümleri yer almaktadır (Resmi Gazete, 2006).

Veteriner hekimlerin tedavi sözleşmesinden kaynaklanan hukukî sorumlulukları da oluşmaktadır. Hasta sahibi ile veteriner hekim arasında bir "vekâlet sözleşmesi” bulunmaktadır. $\mathrm{Bu}$ sözleşme doğrultusunda hasta sahibi, hastasına yapılacak olan tedavi ile ilgili veteriner hekimi vekil tayin etmektedir. Veteriner hekim de sözleşme doğrultusunda hastasını deneyim ve bilgisi ile özenle tedavi etmeli, hasta sahibini aydınlatmalı ve tedavi süreci ile ilgili bildirimlerde bulunmalıdır. Türk Hukukunda tedavi sözleşmesi, vekâlet sözleşmesi şeklinde kabul görmektedir (Özcan ve Özel, 2007; Oral, 2014).

Veteriner hekimler sözleşmenin dişında "haksız fiil, vekâletsiz iş görme ve kusursuz sorumluluk hükümleri" yönünden de sorumlu tutulabilmektedir. Vekâletsiz iş görme, hayvan için acil bir durumda ya da hayvan sahibinin vakanın olduğu yerde bulunmamasından dolayı tedavi sözleşmesi yapılamaması durumunda, veteriner hekimin meslek etiği gereği müdahalede bulunması halinde söz konusu olmaktadır (Oral, 2014).

Veteriner hekimler, "Türk Borçlar Капипи"nun 67. maddesine göre, kendilerine sahipleri tarafından tedavi amaçlı ve geçici olarak bırakılan hayvandan, hayvanı bulunduran ve hayvanın bakımını ve yönetimini üstlenen kişi olarak sayılacağından, “kusursuz sorumlu” olacaktır. Aynı Kanunun 66. maddesine göre, yardımcı sağlık personeli tarafindan hayvana ve dolayısıyla hayvan sahibine zarar veren bir eylemde bulunulmuşsa, bu yardımcı sağlık personeli bağlı bulunduğu veteriner hekimin çalışma alanında istihdam ediliyor, bağlılık ilişkisi içerisinde çalışıyorsa, zarar veren eylem hizmet sırasında meydana gelmiş ise bu kişiyi çalıştıran veteriner hekim, kusursuz dahi olsa personel çalıştırma hükümlerine göre yargılanır. Söz konusu personel ise haksız fiilden yargılanır. Yine aynı Kanunun 71. maddesinde veteriner hekimlerin sorumluluğunda bulunan işletmelerde tehlike arz edecek cihaz/malzemelerin kontrol altında tutulmas1, burada bulundurulan hayvanların da kontrol altında tutulması, tehlikeyi önleme sorumluluğu bulunduğundan kusursuz sorumluluk 
olarak değerlendirilebilmektedir (Resmi Gazete, 2011a; Oral, 2014).

Veteriner hekimlerin meslek hayatları süresince teknolojik gelişmelerle uyum içinde olması gerekliliği de mesleki sorumluluk kapsamında değerlendirilebilecek bir konudur. Hekimin güncel gelişmeleri takip ederek, bilimsel ve mesleki sınırlar içerisinde kalarak, yeni tedavi metotlarını seçmesi ve uygulaması kusur olarak değerlendirilmez (Değdaş, 2018).

\section{MALPRAKTISIN DEĞERLENDİRILMESI}

Veteriner hekimlerin hayvanlara olan sorumluluğu genel olarak ulusal/bölgesel yasalara tabidir. Ev hayvanları da dâhil olmak üzere tüm evcil hayvanlar, malpraktis kaynaklı zararlarda hayvanın mülk olarak görülmesi sebebiyle mal (eşya) olarak değerlendirilmektedir (Hankin, 2007). Amerika Birleşik Devletleri'nde çoğu eyalet malpraktis uygulamalarının, mülk değeri olarak görülen hayvanın adil piyasa değerinin geri kazanılmasının sağlaması hedeflenmiştir (Eichinger, 2006). Tüm eyaletlerde, bu değerler için ortak bir terminoloji yoksa da, bu evcil hayvanın "gerçek değeri" olarak adlandırılabilir. $\mathrm{Bu}$ standarda göre, bir evcil hayvanın ölümüne veya yaralanmasına ihmalkâr bir şekilde neden olan veteriner hekim, evcil hayvanın sahibi için hayvanın sahip olduğu değeri (hayvanın maddi değeri) karşılamakla sorumludur. Bir evcil hayvanın gerçek değeri, aşılama, kısırlaştırma ve eğitim gibi hayvana yapılan yatırımların yanı sıra yeni bir hayvan satın almanın maliyetlerini de içermektedir (Huss, 2002). Fakat bu durum hayvan sahipleri için değerlerini asla karşılayamamaktadır. Hayvanlar ile insanlar arasında oluşan arkadaşlık ve duygusal değerlerin "gerçek değer" kavramına dahil edilmediği görülmektedir (Centner ve Smeshko, 2011).
Sivil toplum örgütleri, hayvan hakları savunucuları gibi bazı gruplar, bir evcil hayvanın kaybının manevi olmayan bileşenlerinin tazminini (Huss, 2004; Livingston, 2004), evcil hayvan sahipleri için vesayet statüsünü (Eichinger, 2006; Helms ve Bain, 2009), yeni bir yasal "evcil hayvan mülkiyeti" kategorisini (Hankin, 2007) ve hayvanlar için hak talep etme hakkının verilmesini istemektedirler (Favre, 2010). Bu görüşler, veteriner hekimlerin yetersiz mesleki uygulamaları için sorumluluklarını önemli ölçüde artırabilmektedir (Centner ve Smeshko, 2011).

\section{Malpraktis İddiaların Sonuçlanması}

Sağlık alanında malpraktis davaları, "kusura (haksız fiile) dayalı" telafi sistemine göre değerlendirilip, sonuçlandırılmaktadır. Türkiye'de uygulanan bu sistemde, kusura dayalı eylemde bulunan kişi ya da kurumun kusuru, yargilama sürecinden sonra belirlenmektedir ve sigorta aracılığı ile ya da direkt bu kişi ya da kurumdan karşılanması sağlanmaktadır (Çokar, 2009).

Yargılama süreçleri sonrasında, tazminatın sigorta aracılığı ile ödenmesi aşamasında, bu sigorta kapsamına yalnızca, serbest, kamu veya özel sağlık kurum ve kuruluşlarında çalışan, tıp hekimleri, diş hekimleri ve tıpta uzmanlık hükümlerine göre mezun olmuş hekimler alınmaktadır (Resmi Gazete, 2010). Tıbbi kötü uygulamaya ilişkin zorunlu mali sorumluluk sigortası ile ilgili veteriner hekimler için henüz bir düzenleme bulunmadığı görülmektedir. Veteriner hekimin kötü uygulamaları ile ilişkili olarak Türk Ceza Kanunu (TCK)'nun “mala zarar verme" (151. madde) suçu ile fiilen benzeri hükümler kapsamında suç duyurusunda bulunulabilir (Resmi Gazete, 2004a; Resmi Gazete, 2004b; Resmi Gazete, 2006). Bununla birlikte "Kişilere karşı işlenen suçlar” başlığı altında, 
“taksirli” ya da "kasten” öldürmeye ve yaralamaya ilişkin hükümler (81.ve 89. maddeler arasında) yer almakta, ancak hayvanların durumuna ilişsin bir detaylandırma bulunmamaktadır. $\mathrm{Bu}$ durumun da veteriner hekimliğinde malpraktisi yorumlarken önemli bir kısıtlılık oluşturduğu söylenebilir.

Veteriner hekimlerin görev ve yükümlülükleri, 6343 sayılı Kanuna dayanılarak hazırlanan "Türk Veteriner Hekimleri Birliği Hizmetlerinin Yürütülmesine İlişkin Uygulama Yönetmeliği” kapsamında açıç̧a belirtilmiştir (Resmi Gazete, 2006). $\mathrm{Bu}$ yükümlülüklere uyulmaması durumunda, veteriner hekimlerin bağlı bulunduğu veteriner hekim odalarına, ihlal ile ilgili hükümler kısaca belirtilerek bir dilekçe ile başvuru yapılır. Veteriner Hekimleri Odası tarafından şikâyet incelemeye alınır ve Oda Haysiyet Divanı'na iletilir. İletilen şikâyet incelenir ve konunun muhatabı veteriner hekim tarafından savunma istenir (Nart, 2020). Haysiyet Divanı, ilgili yönetmeliğin 10 . bölümündeki "Disiplin Suçlart ve Cezalart” uyarınca karar verir. Bu bölümün 116. maddesinde yer alan disiplin cezaları; “(1) Yazılı ihtar, (2) Kanunda belirtilen miktarlarda para cezası, (3) On beş günden altı aya kadar meslek icrasından geçici olarak men kararl, şeklindedir (Resmi Gazete, 2006; Çelik, 2020). Oda Haysiyet Divanı ve Yüksek Haysiyet Divanı tarafından, gerekçesi belirtilerek suçla ilgili, bir üst ceza verebileceği gibi, suçun tekrarlanması durumunda da bir üst ceza da verilebilmektedir. Malpraktis ile ilgili cezaların hangi durumlarda verileceği ile ilgili ayrıntılar da, Yönetmeliğin 116. maddesinde açıç̧a ifade edilmektedir. Öngörülen disiplin cezalarının kesinleşmesi durumunda, eğer eylem TCK'da da suç teşkil ediyorsa (Madde 117), Oda Yönetim Kurulu tarafindan Cumhuriyet Savcılığına suç duyurusunda bulunulması gerekmektedir (Resmi Gazete, 2006).
Oda üyesi olan veteriner hekimler ile ilgili soruşturmada yetkili merci Oda Yönetim Kuruludur. Oda Haysiyet Divanının yetkileri, bağlı bulunduğu oda ile sınırlı olmakla birlikte, bölgeleri dışında oluşan olaylarla ilgili görüşlerini, Merkez Konseyi'ne ve bağlı bulundukları odalara iletebilmektedirler. Merkez Konseyi gerekli değerlendirmeleri yaptıktan sonra, ilgili Oda Yönetim Kuruluna gerekli işlemi bildirir. Bu odalar da soruşturma açılmasına dair Merkez Konseyi'nin isteğini acilen gündeme alır. Soruşturma ile ilgili onaylama ve karar süreci Uygulama Yönetmeliğinin 128. maddesine göre yapılmaktadır. Veteriner hekimin, Oda Haysiyet Divanı tarafindan verilen kararlar için, tebliğ tarihinden itibaren 15 gün içinde Yüksek Haysiyet Divanı'na itiraz başvurusu yapma hakkı bulunmaktadır. İtiraz edilmeyen kararlar ise hemen uygulanmaktadır (Resmi Gazete, 2006). Yüksek Haysiyet Divanı, gelen itirazlarla ilgili 6343 sayılı Kanunun 52, 53 ve 54. maddeleri doğrultusunda işlem yapmaktadır (Resmi Gazete, 1954). Ayrıca Yönetmeliğin 53. maddesi ç bendinde de, veteriner hekimleri odası yönetim kurullarının "meslek hatalarını kovuşturma komisyonu" oluşturabileceği (Resmi Gazete, 2006) ifade edilmiştir. Ancak, veteriner hekim odalarının büyük çoğunluğunda bu komisyonların henüz kurulmadığ söylenebilir.

Veteriner hekime açılabilecek tazminat davaları başlıca "tıbbı kusur" çerçevesinde yer almaktadır. Bu kusur "kast” ya da "ihmal” şeklinde değerlendirilir. Örneğin bir veteriner hekimin kontamine bir tıbbi aleti sterilize etmeden başka bir hayvanda kullanması sonucu hastalık bulaştırması kasti kusur olarak kabul edilir. Operasyon sırasında hasta vücudunda cerrahi alet unutulması "ă̆gr ihmal", bir cerrahi aletin bozuk olduğu, ancak 
dikkatle ve özenle kullanıldığında işlevini yerine getirebileceği öngörüsünde bulunamamak "hafif ihmal" olarak değerlendirilir. Bu kusurların derecesi tazminat miktarına etki etmektedir (Erol Sarıyev, 2016).

Hayvanın yaşam standartlarını bozacak ya da bedensel bütünlüğüne zarar verecek her türlü tıbbi müdahale, hukuka aykırı ve kusurlu uygulamalardır. Dolayısıyla da hayvan sahibi böyle bir durum neticesinde maddi-manevi zarar görmüş ise veteriner hekime tazminat davası açabilir. Maddi tazminat davalarının amacı, hayvan sahiplerinin mal varlığının (hayvan) önceki durumuna gelmesini sağlamaktır. Bundan dolayı zarara uğranılan miktardan daha fazla tazminata karar verilemez (Oğuzman ve ark., 2012). Hayvan sahibi sadece uğradığı fiili zararı ve bu sürede elde edemediği kârını talep edebilir. Manevi tazminat davalarında ise hayvan sahibinin kaybı sonrasında yaşayacağı acı, keder, 1stırap gibi duyguları ya da yaşama sevincini kaybetmesi gibi manevi durumların da giderilmesini amaçlar (Erol Sarıyev, 2016). Ancak buradaki durum da genel olarak TCK'nın 151. maddesinde yer alan "mala zarar verme" kapsamında ele alınmaktadır (Resmi Gazete, 2004b). Burada ticari amaçla beslenen, ekonomik değeri olan hayvanlarla, duygusal anlamda bağ kurularak bakılan, manevi değer atfedilen (arkadaş) hayvanlar arasında herhangi bir ayrım yapılmadığı söylenebilir.

Veteriner hekimin malpraktis ve sözleşme dışı hallerden dolayı açılan maddi/manevi tazminat davalarında Hukuk Mahkemeleri yetkilidir (Resmi Gazete, 2011b). Veteriner hekim ile hayvan sahibi arasında sözleşme bulunmadığı durumlarda, "Hukuk Mahkemeleri Kanunu” "nun 2. maddesi gereği "Dava konusunun değer ve miktarına bakılmaksızın malvarlı̆ğ haklarına ilişsin davalarla, şahıs varlığına ilişkin davalarda görevli mahkeme, aksine bir düzenleme bulunmadlkça asliye hukuk mahkemesidir" hükmü bulunmaktadır (Resmi Gazete, 2011b). Yani, serbest çalş̧an veteriner hekimler veya yardımcı sağlık personeli ile ilgili haksız fiillerde, istihdam etme sorumluluğu ya da vekâletsiz iş görme hükümlerine dayanılarak, "Asli Hukuk Mahkemesi" nde maddi manevi tazminat davası açılabilir (Erol Sarıyev, 2016).

"Adlî Yargı İlk Derece Mahkemeleri ile Bölge Adliye Mahkemelerinin Kuruluş, Görev ve Yetkileri Hakkinda Kanunu"nun 5. maddesinde belirtildiği üzere; "Asliye hukuk mahkemeleri, sulh hukuk mahkemelerinin görevleri dışında kalan ve özel hukuk ilişkilerinden doğan her türlü dava ve işler ile kanunların verdiği diğer dava ve işlere bakar." (Resmi Gazete, 2004c). Malpraktis sonucunda zarara uğramış bir hayvan sahibi, haksız fiillerden doğan borç kapsamında, "Türk Borçlar Kanunu"nun 49. maddesine göre de dava açabilmektedir. Haksız fiil kapsamında, haklara sahip olan kişiler, hayvanların kendi kaderini belirleyememesi, kendisine yapılacak işlemlere izin verememesi sebebiyle hasta sahipleridir. Hasta sahiplerinin, hayvan üzerinde mülkiyet hakk1 olduğundan dolayı, bu kişilerin tedavi öncesi verdiği rızanın sorumluluğu engelleyeceği kabul edilmektedir (Oral, 2014). Kanunun 50. maddesine göre zarar gören, zararı ve zarar verenin kusurlu olduğunu ispatlamak zorundadır. Kamu dışında çalışan sağlık personelinin sebep olduğu zararın tazmini için Borçlar Hukukunun genel çerçeveleri doğrultusunda tazminat davası açılabilmektedir (Resmi Gazete, 2011a; Erol Saryev, 2016). Kanunun 72. maddesine göre de dava, taraflar davayı öğrendikten sonra iki yll ve eylemin gerçekleşmesini takip eden 10 yll boyunca geçerlidir. Bu sürelerin geçirilmesi davanın zaman 
aşımına uğramasına sebep olur (Resmi Gazete, 2011a).

Kanunlarda yer alan istisnai durumlar dışında hekimler tarafindan yapılan "endikasyonsuz tıbbi müdahale”'lerde tümüyle hukuka aykırı olarak değerlendirilmektedir (Hakeri, 2014). Bu müdahaleler olası kasıt oluşturmaktadır. Veteriner hekimliğinde de hayvanlara gerekmediği halde fazladan çeşitli ilaç ve biyolojik madde uygulanması ve bu uygulamaların malpraktise neden olduğu durumlarla karşılaşılabilir. $\mathrm{Bu}$ ve benzeri endikasyonsuz tıbbi müdahaleler, hayvanın zarar görmesi ve malpraktise neden olması ihtimali nedeniyle kaçınılması gereken müdahalelerdir.

Bazı durumlarda veteriner hekimin neden olduğu malpraktis, konu ile ilgili yeterli bilgiye sahip olmayan hasta sahibi tarafından ispat edilemeyebilir. $\mathrm{Bu}$ gibi durumlarda tıp hekimliğinde olduğu gibi veteriner hekimliğinde de bilirkişi incelemelerinin devreye sokulması gerekebilir (Erol Sarıyev, 2016).

\section{MALPRAKTISININ ÖNLENMESI}

Veteriner hekimliğinde malpraktis iddialarının azaltılmasına yardımcı olabilecek faktörler, eksiksiz muayene, kaliteli tedavi, iyi tutulmuş medikal kayıtlar, aydınlatılmış onam ve eksiksiz hayvan/hasta sahibi iletişimidir (Meagher, 2005). Herhangi bir komplikasyon meydana gelmesi ihtimali zamanında fark edilmişse, gerekli önlemlerin alınması sağlanmışsa ya da önlemler alınmış ve standartlaşmış gerekli tıbbi girişimlerde bulunmuşsa malpraktis meydana gelmesi önlenecektir (Sağesen, 2013).

Amerika Veteriner Hekimleri Birliği (AVMA), olası malpraktis iddialarının ya da şikâyetlerin azaltılması için veteriner hekimlere çeşitli tavsiyelerde bulunmuştur, Bunlar;
1) Tedaviden önce; Hasta sahibine tedavi seçenekleri, tedavinin riskleri ve tahmini maliyet hakkında bilgilendirme yapılarak aydınlatılmış onam formu düzenlenmelidir. Uygulanacak tedavi protokolünün hasta sahipleri tarafindan iyi anlaşıldığından emin olunmalıdır. Konu ile ilgili uzmanlığın yetersizliğinde müdahalede bulunmamalı ve uzman desteği alınmalıdır. Gelen hastanın başka bir veteriner hekim tarafından tedavi altında olup olmadığg öğrenilmelidir. Böyle bir durum mevcut ise gerekli kayıtların temin edilmesi istenmelidir. Veteriner hekimler çalıştıkları yerlerde, tercih edilen teşhis ve tedavi prosedürü için yeterli ekipmana sahip değilse hastaya sevk teklif edebilir. Acil müdahalelerde sevk mümkün değilse hasta sahipleri riskler hakkında detaylı olarak bilgilendirilmeli ve yazılı onay alınmalıdır. Hastanın tıbbi kaydı, tahmini tedavi prosedürü mutlaka kayıt altına alınmalıdır (AVMA, 2020).

2. Tedavi sırasında; Uygulamalar esnasında yapılan muayene bulgularının ve tedavi yöntemlerinin doğru ve detaylı kayıtlarının tutulması sağlanmalıdır. Hayvanların zapt-1 raptı için profesyonel destek alınmalıdır. Tedavi süreci, yapılış şekli, prognozu ve maliyete yansımaları hakkında hayvan/hasta sahipleri ile düzenli olarak iletişimde olunmalıdır (AVMA, 2020).

3. Tedavi sonrasında; Ölüm sebebinin belirlenmesi için hasta sahiplerine her zaman, mümkünse bir veteriner patalog tarafından yapılacak otopsi seçeneğinin sunulması gerekmektedir. Hasta sahipleri ile iletişim devam ettirilerek, her zaman gerçekler söylenmeli, tahminden kaçınılmalıdır. Tıbbi ya da radyografik kayıtların orijinallerini yayınlamak yerine, talep ya da yasal gereklilik halinde kopyalarının tedarik edilmesi sağlanmalıdır (AVMA, 2020). Bu kayıtları basılı kopya ya da 
elektronik dosyalarda belgeleyebilmek için sistemler geliştirilmeli ya da var ise bu sistemler kullanılmalıdır. Ayrıca bu kayıtlara (özellikle hekimlerin karşı taraftan yeterince dinlenmediklerini düşündüklerinde) danışanlara yapılan tüm tavsiyeleri de eklemek önerilmektedir (Wilson, 2011). Tıbbi kayıtlar, yanlış uygulamalarda önemli kanıtlar oluşturabilir ve bu nedenle veteriner hekimler, bunların uygun şekilde muhafaza edilmesine büyük özen göstermelidir (McEachern, 2004).

Günümüzde hayvanların zapt edilmesinin sahipleri tarafindan yapılması sorgulanmaktadır. Çünkü insanlar, hayvanlar ya da işletmede çalışan personel, yeterli zapt-1 raptın sağlanamaması durumunda çeşitli kazalara maruz kalmaktadır. Hayvan sahipleri zoonoz hastalıklar ve paraziter hastalıklara karşı alınabilecek önlemler hakkında yeteri kadar bilgilendirilmelidirler. Ayrica hasta sahiplerinin bekleme alanında hayvanları ile birlikte bulundukları sırada hayvanlarının kaçmalarını, başka bir hayvana ya da insana zarar verme durumunu önlemek amacıyla belirli uyarıların ya da yönlendirmelerin yapıldığı ve sorumluluğun hasta sahiplerinde olduğunu belirten uyarılar bulundurması, bu durumun yol açabileceği olası malpraktis durumlarının ve davalarının önüne geçebilir (Wilson, 2011).

Aydınlatılmış onamın amacı, hasta sahibine tavsiye edilen sağlık bakımı hakkında bilinçli bir karar verebilmesi için hasta sahibine yeterli bilgi vermektir (Flemming, 2004). Tıbbi bilgilendirilmiş onam prosedürleri, klinisyen veteriner hekimlerin hasta sahibi saldırısı veya görevi kötüye kullanma suçlamalarından korunmasında önemli bir rol oynar (Jackson, 2016). Aydınlatılmış onam aynı zamanda hem hayvan sahibi hem de veteriner hekim için yasal koruma sağlamak adına kullanılır (Flemming, 2004) ve bazı kaynaklarda öncelikle bir risk yönetimi aracı olarak tanımlanmıştır (Martin, 2006).

Sağlık sisteminde meydana gelen sorunlar her geçen gün artmakta, bu durum da malpraktis vakaları ve bu vakalardan kaynaklanan ceza ve hukuki davalarının ve mesleki sigorta sayılarının artmasına yol açmaktadır (Koç, 2007). Beşeri hekimlerim mesleki sorumluluk sigortası, görevlerini yerine getirirken ihmal, yanlış uygulama ya da hata gibi durumların sonucunda oluşacak zararların tazmini ve ilgili maddi zararlardan hekimi korumak amacıyla yapılmaktadır. Hekimlerin ve sağlık kuruluşlarının bu sigorta sayesinde malpraktisten doğan zararları da teminat altına alınmaktadır (Gökmen ve Güleç, 2010). Oysaki Türkiye'de bu sigortaların malpraktis sonucunda oluşabilecek mağduriyetlere karşı talep edilebilecek maddi tazminatlar için veteriner hekimi güvence altına almasına rağmen, birçok veteriner hekimin sorumluluk sigorta poliçesine sahip olmadığ görülmüştür (Nart, 2020).

\section{SONUÇ ve ÖNERILER}

Veteriner hekimlerin hukuki sorumluluğu, hukuken kişilik hakkı bulunmayan "hayvanlarl" tedavi ettikleri için beşeri hekimlerin sorumluluklarından ayrılmaktadır. İnsanların kişilik haklarına saldırı durumunda hekimlerin karşılaştıkları sonuçlar ile hayvanların zarar görmesi sonucu veteriner hekimlerin karşılaştıkları sonuçlar aynı olmasa da, veteriner hekimlerin de hayvanların acı, ağrı, ıstırap duyduklarını, onların da hissedebilen varlıklar olduğunu yani "eşya” dan farklı olduklarını göz önünde bulundurması ve yapılan tedavilerde maksimum özeni göstermeleri gerekmektedir (Oral, 2015).

Mevcut yasalara göre hayvanlar, mülk olarak değerlendirilmekte, bu da evcil hayvan sahiplerinin, 
veteriner hekimliği malpraktis tazminini gerektiği gibi anlamadıkları anlamına gelmektedir(Centner ve Smeshko, 2011). Bu duruma yanit vermek ve bu hayvanların gerçek değerini tanımak için bugün birçok ülke anayasasında olan hayvanların haklara sahip olduğu ve eşya olarak kabul edilmediğine yönelik düzenlemeler emsal alınarak, mevzuatın yeniden düzenlenmesi ve malpraktise ilişkin özel bir düzenleme yapılması gerektiği söylenebilir.

Veteriner hekim adaylarının, eğitimleri sırasında icra edecekleri mesleğin mevzuatı, hukuki hak ve sorumlulukları ile ilgili yeterli bilgi edinmesi, yasal anlamda karşılaştığı tüm durumları kavraması ve malpraktis iddialarına karşı nasıl tavır alması gerektiği konusunda yol gösterici olabilir.

Sahip olunan veteriner hekimlik bilgi ve becerilerinin yeterli olabilmesi için her zaman veteriner hekimliği ile ilgili güncel araştırma ve gelişmeler takip edilmelidir. $\mathrm{Bu}$ güncellemelerin veteriner hekime, hastalara yaklaşımda ve tedavinin geçerliliği ve yeterliliği çerçevesinde yarar sağlayacağı söylenebilir.

Tedavi sürecini hasta sahipleri ile açık bir şekilde konuşmak ve aydınlatılmış onam formu düzenlemek yararlı olabilmektedir. Olası bir şikâyeti yüz yüze konuşma ve her türlü durumu açıklığa kavuşturmak açısından daha etkili olacağ söylenebilir.

Veteriner hekimler ihmal davaları nedeniyle mağduriyet yaşamamak ve olası iddialara karşı kendilerini güvence altına alabilmek için, hekim sorumluluk sigortasına başvurabilirler. $\mathrm{Bu}$ uygulamalar hakkında veteriner hekimlerin daha fazla bilgilendirilmesi ve sigorta uygulamalarının yaygınlaştırılması önerilebilir.

Sonuç olarak Türkiye'de veteriner hekimliğinde malpraktis ile ilgili kaynakların yetersiz olması, var olan çalışmaların önemli bir kısmının tıbbi malpraktis ile ilgili yapılan çalışmalar olması, malpraktis üzerine veteriner hekimliği alanında yasal bir düzenleme olmaması önemli bir sorun teşkil etmektedir. $\mathrm{Bu}$ bağlamda veteriner hekimliği alanında konu ile ilgili bilimsel araştırmaların artırılması ve malpraktise ilişkin yasal düzenlemelerin oluşturulması gerektiği söylenebilir.

\section{KAYNAKLAR}

Aktaş, EÖ. (2020). Pediatrik onkolojide hukuksal sorumluluk. [Erişim tarihi: 06 Aralık 2020]. Erişim linki: http://tpog.org.tr/uploads/19_Sunum/ 15.30\%20-\%20Ekin\%20\%C3\%96zg\%C3\%BCr $\% 20 \mathrm{Akta} \% \mathrm{C} 5 \% 9 \mathrm{~F} . \mathrm{pdf}$.

Alman Medeni Kanunu (2002). 2 Ocak 2002. [Erişim tarihi: 06.04.2021]. Erişim linki: https://www.gesetze-im-internet.de/englisch bgb/englisch_bgb.html\#p0272.

AVMA (2020). Amerikan Veteriner Hekimler Birliği, Client management guidelines; reduce the likelihood of malpractice allegations and board complaints. [Erişim tarihi: 11 Ekim 2020]. Erişim linki: https://www.avmaplit.com/uploadedfiles/ avma_plit/resources/public_resources/client $\% 20$ management\%20guidelines-2018update.pdf.

Avusturya Medeni Kanunu (1988). 01 Temmuz 1988. [Erişim tarihi: 06.04.2021] Erişim linki: https://www.jusline.at/gesetz/abgb/paragraf/285a.

Babacan, E., Öztürk, H., \& Kahriman, İ. (2018). Tibbi hatalar ve hasta güvenliği: Hemşirelere yönelik eğitimlerin etkinliğinin değerlendirilmesi. Sağllkta Performans ve Kalite Dergisi, 14(2), 5772.

Centner, TJ., \& Smeshko, N. (2011). Compensating companion animal owners for veterinary malpractice through an alternative dispute resolution mechanism. Journal of Social Sciences, 7(4), 597-604.

Cekya Medeni Kanunu (2012). 03 Subat 2012. [Erișim tarihi: 06.04.2021]. Erişim linki: http://obcanskyzakonik.justice.cz/images/pdf/Civi 1-Code.pdf.

Çelik, F. (2020). Cerrahın yasal sorumlulukları. [Erişim tarihi: 06 Aralı 2020] Erișim linki: https://www.medimagazin.com.tr/guncel/trcerrahin-yasal-sorumluluklari-11-666-7204.html.

Çokar, M. (2009). Türkiye'de malpraktis konusunda yasal düzenleme girişimleri: Zorunlu mali sorumluluk sigortası bir çözüm müdür? Türkiye Biyoetik Derneği e-Bülteni, 19, 7-16.

Coltu, A. (2012). Tıbbi Uygulama Hataları. Koç S. 1st ed. 1.Tıp Hukuku Günleri Tıbbi Uygulama Hataları, İstanbul, Turkey: İstanbul Tabip Odası Yayınları

Değdaş, UC. (2018). Hatalı tıbbi uygulamadan (malpraktis) doğan hukuki ve cezai sorumluluk. Hukuk Fakültesi Dergisi, 1(6), 41-65. 
Eichinger, GL. (2006). Veterinary medicine: External pressures on an insular profession and how those pressures threaten to change current malpractice jurisprudence. Mont. Law Rev, 67, 231-274.

Erol Sarıyev, A. (2016). Veteriner hekimin sözleşme dış1 sorumluluğu. TBB Dergisi, 127, 264-298.

Favre, D. (2010). Living Property: A new status for animals within the legal system. Marquette Law Rev, 93, 1021-1071.

Federal Alman Cumhuriyeti Anayasası (2014). 23 Aralık 2014. [Erişim tarihi: 06.04.2021]. Erişim linki: file:///C:/Users/USER/Downloads/Grundgesetz_T R_endgltig.pdf.

Flemming, DD., \& Scott, E. (2004). The informed consent doctrine: what veterinarians should tell their clients. JAVMA, 224(9), 1436-1439.

Gardiner, A., Corr, S., Palmer, C., \& Sandøe, P. (2015). Companion Animal Ethics. The development and role of the veterinary and other professions in relation to companion animals. Ed: Sandøe P, Corr S, Palmer C. United Kingdom: Wiley-Blackwell; 2015. pp. 24-40.

Gökmen, H., \& Güleç, S. (2010). Tibbi malpraktis riskinin yönetiminde bir araç olarak hekim mesleki sorumluluk sigortaları. Sağlıkta Performans ve Kalite Dergisi, 1, 9-16.

Hakeri, H. (2014). Ceza Hukuku: Genel Hükümler, Temel Bilgiler. Güncellenmiş ve genişletilmiş 11. Bask1, Ankara, Turkey: Seçkin Yayıncılık.

Hanc1, İI. (2005). Malpraktis mi? Komplikasyon mu? Mevzuat Dergisi, 90(8), 1.

Hankin, SJ. (2007). Not a living room sofa: Changing the legal status of companion animals. Rutgers Journal of Law \& Public Policy, 4(2), 314-309.

Helms, TD., \& Bain, MJ. (2009). Evaluation of owner attachment to dogs on the basis of whether owners are legally considered guardians of their pets. J. Am. Vet. Med. Assoc, 234, 896-900.

Hessler, KM. (2006). Mediating animal law matters. Journal of Animal Law \& Ethics, 2(21), 21-75.

Huss, RJ. (2002). Valuing man's and woman's best friend: The moral and legal status of companion animals. Marq. Law Rev, 86, 47-105.

Huss, RJ. (2004). Valuation in veterinary malpractice. Loyola University Chicago Law Journal, 35(2), 459-453.

İsviçre Medeni Kanunu (1907). 10 Aralık 1907. [Erişim tarihi: 06.04.2021]. Erișim linki: https://www. fedlex.admin.ch/eli/cc/24/233_245_233/en.

Jackson, E. (2016). Consent I: Understanding. In: Medical Law: Text, Cases and Materials. United Kingdom, Oxford University Press.

Koç, S. (2007). Yasal düzenlemeler çerçevesinde hekim sorumluluğu. Türkderm. 41, 33-38.

Koç, S. (2014). Adli tıbbi açıdan malpraktis ve hekimin sorumluluğu. Toraks Cerrahisi Bülteni, 5(1), 1422.

Livingston, M. (2004). The calculus of animal valuation: Crafting a viable remedy. Nebraska Law Rev, 82, 783-748

Martin, EA. (2006). Managing client communication for effective practice: What skills should veterinary graduates have acquired for success? JVME, 33(1), 45.

Meagher, DM. (2005). A review of equine malpractice claims. AEPP Proceedings, 51, 508-514.

McEachern, MM., \& Weedon, GR. (2004). Modern trends in veterinary malpractice: How our evolving attitudes toward non-human animals will change veterinarian medicine. Animal Law, 10(125), 125161.

Nart, A. (2020). Veteriner Hekimler için mesleki sorumluluk sigortası nedir? [Erişim tarihi: 12 Ekim 2020]. Erişim linki: https://veterinerturkiye. com/veteriner-hekimler-icin-mesleki-sorumluluksigortasi-nedir/.

Oğuzman, MK., Seliçi, Ö., \& Oktay Özdemir, S. (2012). Eşya Hukuku. 15. Bask1, İstanbul, Turkey: Filiz Kitabevi.

Oral, T. (2014). Veteriner hekimin sözleşme dış1 sorumluluğu. Türkiye Adalet Akademisi Dergisi, 5(16), 319-335.

Özcan, BG., \& Özel, Ç. (2007). Kișilik haklar1- Hasta hakları bağlamında tıbbi müdahale sonucu çıkan hukuki ilişkide aydınlatma yükümlülüğü ve aydınlatılmıș rızaya ilișkin bazı değerlendirmeler. Hacettepe Sağlık İdaresi Dergisi, 10(1), 51-73.

Özçetin, E. (2016). Sağlık alanında malpraktis. İstanbul, Turkey, Thesis of $\mathrm{PhD}$, Beykent Üniversitesi Sosyal Bilimler Enstitüsü.

Pugliese, M., Voslarova, E., Biondi, V., \& Passantino, A. (2019). Clinical practice guidelines: an opinion of the legal implication to veterinary medicine. Animals, 9(8), 577.

Resmi Gazete (1954). 6343 sayılı Veteriner Hekimliği Mesleğinin İcrasına, Türk Veteriner Hekimleri Birliği ile Odalarının Teşekkül Tarzına ve Göreceği İşlere Dair Kanun. 18 Mart 1954. https://www.mevzuat.gov.tr/MevzuatMetin/1.3.6 343.pdf.

Resmi Gazete (2004a). 5199 say1lı Hayvanları Koruma Kanunu. 24 Haziran 2004. [Erişim tarihi: 06.04.2021]. Erişim linki: https://www.mevzuat. gov.tr/MevzuatMetin/1.5.5199-20100611.pdf.

Resmi Gazete (2004b). 5235 sayılı Adlî Yargı İlk Derece Mahkemeleri ile Bölge Adliye Mahkemelerinin Kurulus, Görev ve Yetkileri Hakkında Kanun. 07 Ekim 2004. https://www.resmigazete.gov.tr/ eskiler/2004/10/20041007.htm\#1.

Resmi Gazete (2004c). 5237 sayılı Türk Ceza Kanunu. 26 Eylül 2004. https://www.mevzuat.gov.tr/Mevzuat Metin/1.5.5237.pdf.

Resmi Gazete (2006). Türk Veteriner Hekimleri Birliği Hizmetlerinin Yürütülmesine İlișkin Uygulama Yönetmeliği. 13 Eylül 2006. https://www. resmigazete.gov.tr/eskiler/2006/09/200609139.htm.

Resmi Gazete (2010). Tıbbi Kötü Uygulamaya İlişkin Zorunlu Mali Sorumluluk Sigortasinda Kurum Katkısına İlişkin Usul ve Esaslara Dair Tebliğ. 21Temmuz 2010. https://www.resmigazete.gov.tr/ eskiler/2010/07/20100721-17-1.htm.

Resmi Gazete (2011a). 6098 sayılı Türk Borçlar Kanunu. 04 Şubat 2011. https://www.mevzuat.gov.tr/ MevzuatMetin/1.5.6098.pdf. 
Resmi Gazete (2011b). 6100 sayılı Hukuk Mahkemeleri Kanunu. 04 Şubat 2011. https://www.mevzuat. gov.tr/MevzuatMetin/1.5.6100.pdf

Sağesen, SS. (2013). Malpraktis. [Erişim tarihi: 19 Ekim 2020]. Erişim linki: https://slideplayer.biz.tr/ slide/2749416/.

Schnobel, SA. (2016). Prioritising the best interests of the animal and re-framing veterinary negligence. Birmingham, England, Thesis of Doctoral, The University of Birmingham.

Şahin, AB. (2021). T1bbi malpraktis (hatalı tıbbi uygulama) - komplikasyon ayrımı ve buna ilişkin sorumluluklar. [Erişim tarihi: 05.05.2021]. Erişim linki: https://kplegal.com.tr/tibbi-malpraktishatali-tibbi-uygulama-komplikasyon-ayrimi-vebuna-iliskin-sorumluluklar.

Tuğcu, H., Yorulmaz, C., \& Koç, S. (2009). Hekim sorumluluğu ve tıbbi malpraktis. Klinik Gelişim, 22, 6-10.

TDK (2013). Türk Dil Kurumu, Malpraktis. Büyük Türkçe Sözlük, Ankara, Turkey.

TDK (2020). Türk Dil Kurumu, [Erişim tarihi: 15 Ekim 2020]. Erişim linki: https://sozluk.gov.tr/.

TTB (2012). Türk Tabipler Birliği, Hekimlik Meslek Etiği Kuralları, Ankara, Turkey. [Erişim tarihi: 15 Ekim 2020]. Erişim linki: https://www.ttb.org.tr/mevzuat/index.php?option $=$ com_content $\& \mathrm{id}=65 \&$ Itemid $=31$
TVHB (2010). Türk Veteriner Hekimleri Birliği, 3. Türk Veteriner Hekimliği Kurultayı. Serbest Veteriner Hekimlik Komisyonu Sonuç Raporu. Ankara, Turkey: 2010. pp. 235-276.

TVHB (2018). Türk Veteriner Hekimleri Birliği, 4. Türk Veteriner Hekimliği Kurultayı. Kamu ve Serbest Veteriner Hekimlik Komisyonu Raporu, Ankara, Turkey, 2018. pp. 197-245.

Walker, JB. (2009). Food animal medicine in crisis. JAVMA, 235(4), 368-374.

White, S. (2009). Companion animals: Members of the family or legally discarded objects? UNSW Law Journal, 32(3), 852-878.

Wilson, JF. (2011). The Law of Professional Negligence. İndianapolis, USA: Priority Press Ltd.

Woodward, LE., \& Bauer, AL. (2007). People and their pets: A relational perspective on interpersonal complementarity and attachment in companion animal owners. Society and Animals, 15, 169-189.

Yaşar, A. (2014). Veteriner hekimliği etiği ve mevzuatı ders notları. Konya, Turkey: Selçuk Üniversitesi Yayınları. 